\title{
Environmental Safety Management of a Coal Mining Enterprise
}

\author{
Golofastova Natalya N. ${ }^{\mathrm{a}}$, Mikhailov Vladimir G. ${ }^{\mathrm{b}}$, Galanina Tatiana V. \\ T. F. Gorbachev Kuzbass State Technical University \\ Kemerovo, Russian Federation \\ ae-mail: gnn.eomp@kuzstu.ru, be-mail: mvg.eohp@kuzstu.ru, ${ }^{\mathrm{c} e-m a i l: ~ e a k e m @ m a i l . r u ~}$
}

\begin{abstract}
The purpose of the study is an analysis of the environmental safety performance at the local level (a coal mining enterprise) and proposals for improvement of the management decision support mechanism aimed at the environmental safety improving. The results of the study of theoretical and applied aspects of environmental safety management process in relation to coal producers are presented, the problems providing for the identification, the selection of the methods for the calculation and estimation of environmental safety indicators have been identified and solved. The basic strategies to ensure environmental safety of the enterprise depending on the existing environmental management system are considered. The analysis of the major ecological and economic indicators of a coal mining enterprise, which characterize the state of its environmental safety, is conducted. The main result of the study is the development of the proposals for improving the management decision-making support mechanism aimed at improvement of environmental safety of the coal enterprises, including technical-technological and business measures. The developed innovative proposals can be used to ensure the environmental safety at various coal mining enterprises.
\end{abstract}

Keywords - coal mining industry, environmental safety, negative impact, environment, environmental, safety performance, environmental and economic risks, environmental management system, management decision-making support mechanism.

\section{INTRODUCTION}

The safety issue is an important area of activity of any industrial enterprise. In the broad sense the security is a condition in which there is no hazard chance or there is an adequate protection [1]. Its level depends on potential hazards, including anthropogenic (human activity) and natural phenomena.

The management of natural emergency and its consequences due to their scale can be implemented at the national level only. In turn, enterprises may prevent and eliminate the consequences of their economic activity, therefore, a gradual process of the impact on the ecosystem begins there.

For a coal operation, the ecological safety means the condition of its production and business activities, which presents no risk to the environment and a human, is adapted to the needs of people, and eliminates any risk to their health and future generations.

Ensuring the environmental safety at a coal-mining enterprise in most cases is implemented by means of technical and technological measures. The value of organizational and managerial solutions for the environmental safety significantly increases in modern practice. Whereby the enterprise can be regarded as a system consisting of a plurality of subsystems including three interrelated environmental management levels:

- lower - the workplace;

- medium - workshops, production works, services, departments;

- higher - the entire enterprise.

The efficiency of the environmental safety management at every level determines largely the managerial efficiency at the next steps. This is due to the fact that the costs required to address the causes of danger at the local workplace is significantly less than those required for the elimination of the adverse effects on the level of the enterprise. Thus, the environmental safety management in the company consists of two main aspects - industrial safety management and environmental management.

Environmental safety management system is created to maintain such environmental and occupational characteristics that meet the needs of people, do not threaten their health, the environment and meet the long-term objectives of the enterprise at all stages of the life cycle of products. Depending on the degree of integration of occupational safety and environmental protection, as well as the nature of the activities for reducing the production risks, four strategies used by industries to ensure environmental safety can be defined:

1. Occupational health and the environment protection problems solved by extensive methods apart from each other (use of personal protective equipment, installation of water treatment facilities and equipment, the closed water circulation cycles).

2. Occupational health and the environment protection problems considered as interconnected and solved by extensive methods (installation of ventilation systems and gas cleaning and dust trapping equipment to meet the requirements of occupational safety and environmental protection) 
3. Protection of workers and the environment carried out using the preventive methods; the measures being aimed at addressing only one of these problems (use of safe processes and materials or the use of low-waste and non-waste technologies).

4. Occupational health and the environment problems considered as interconnected and solved by complex activities of a preventive nature (use of safe processes and materials, processing techniques, use of safe production-based low-waste and non-waste technologies, including those organized using the best available technologies) [1].

The purpose of the study is the analysis of the coal-mining enterprise environmental safety indicators and proposals for the improvement of the management decision support mechanism aimed at its environmental safety improving.

Scientific novelty of the results of the work is to clarify and develop the theoretical, methodological and practical foundations for the studies of environmental safety management process of the coal mining enterprise, expanding the scientific beliefs on content and specifics of green production management.

The developed proposals have practical significance for the environmental safety of coal producers.

\section{SUBJECT OF RESEARCH}

The object of the research is the environmental safety management system of the coal-mining enterprises. The subject of the research is to ensure the environmental safety of the enterprise on the example of JSC "Open-pit Inskoy" on the basis of a system of environmental and economic indicators. This company makes all kinds of negative impacts on the environment. To study this process, the statistical processing of environmental data was carried out on the basis of reporting forms:

- № 4-OS - Information on the current expenditure on environmental protection and environmental payments;

- № 2-TP (air) - Information on air protection;

- № 2-TP (waterworks) - Information on water use;

- № 2-TP (wastes) - Information on production, use, neutralization, transportation and disposal of production and consumption wastes.

To assess the environmental safety of the enterprise, the methods for the study of environmental and economic risks were used, including ranking and interpretation of the range of values of the most reliable environmental and economic indicators.

\section{RESULTS AND DISCUSSIONS}

The problem of environmental safety of the coal mining enterprise has its own characteristics [2, 3], so the authors [4] have developed the geoecological model of the coal mine presented in Fig. 1.

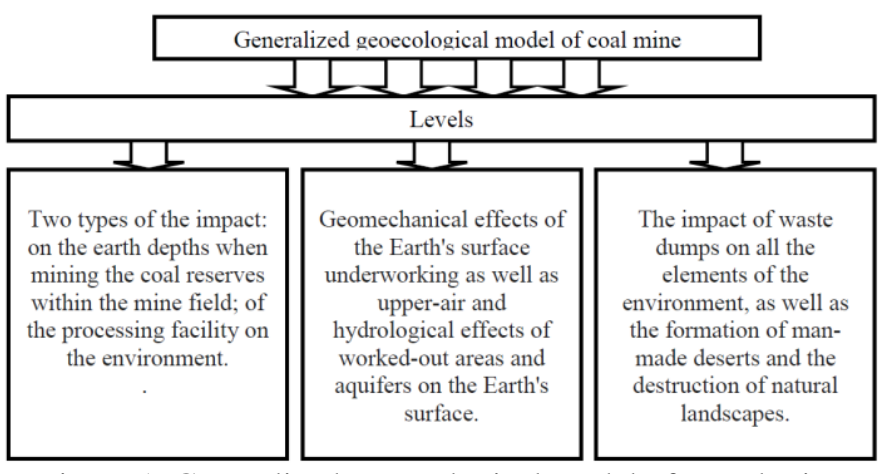

Figure 1. Generalized geoecological model of a coal mine

The first two levels shown in Fig. 1 form the first geotechnological period (development of coal reserves in accordance with the design), and the third one generates the second period, which means the pit closure and the further period of the former mining dump existence.

This geo-ecological model of a coal mine justifies the need for the adequate assessment of efficiency of environmental safety management process, the algorithm of which can be divided into several stages (Figure 2).

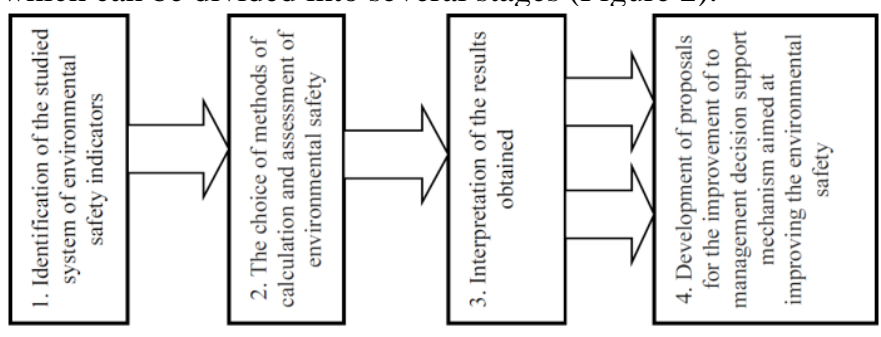

Figure 2. The algorithm for the assessment of the environmental safety management efficiency

At the first stage, the calculation of the basic environmental safety parameters is appropriate $[5,6]$.

The second and third stages include the assessment and the calculation of environmental safety parameters as well as the interpretation of the results. The final stage of the algorithm is dedicated to the development of proposals for improving the management decision support mechanism aimed at the improvement of the environmental safety of coal producers [7].

To assess the environmental safety, it is appropriate to calculate the environmental and economic indicators presented in Fig. 3 characterizing most clearly the company losses associated with the adverse effects on the environment $[8,9,10]$.

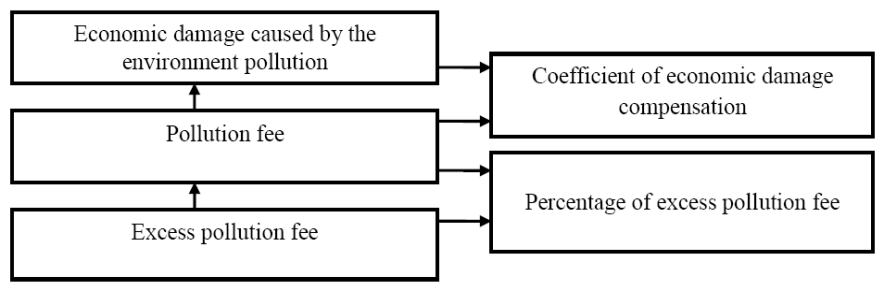

Figure 3. Interrelation of basic and economic indicators of an enterprise 
Basing on the proposed algorithm, the first stage determines the system of the studied environmental and economic indicators depending on the available information base and the required input data reliability degree. The economic damage caused by environmental pollution is identified with the economic losses caused by adverse anthropogenic impact on the environment. The charges for negative impact on the environment (pollution fee) present mandatory payment for all enterprises and institutions engaged in emission of pollutants into the atmospheric air; discharge of pollutants and other substances and microorganisms into surface water, ground water bodies and catchment areas; industrial and consumer waste disposal.

The coefficient of economic damage compensation, which is calculated as the ratio between the pollution fee and the economic damage caused by environmental pollution, reflects the level of reduction of the harmful effects. It is the main indicator of environmental and economic sustainability of the enterprise, which must be set to $\geq 100 \%$. The share of the excess pollution fee in the total value characterizes the excess of the established waste emission, discharge or disposal limit and from the perspective of environmental safety should be set to 0 . In addition, some authors propose to introduce an indicator such as specific pollution fee charge, determined by the ratio of the total pollution fee to the production volume or other enterprise performance indicator, for evaluating the environmental component of enterprises' activity. The specific fees for negative impact on the environment, water consumption and the use of other material and labor resources can be used for the evaluation of the best available technologies.

Table 1 shows the dynamics of the basic environmental and economic performance of JSC "Open-pit Inskoy" [8].

Table 1. Basic environmental and economic performance

\begin{tabular}{|c|c|c|c|}
\hline Indicator & $\begin{array}{c}\text { Unit of } \\
\text { measurement }\end{array}$ & 2013 & 2014 \\
\hline $\begin{array}{l}\text { Economic damage caused by the } \\
\text { environment pollution, including: }\end{array}$ & thousand rubles & 2913.66 & 3447.3 \\
\hline Air pollution & thousand rubles & 581.31 & 599.31 \\
\hline Contamination of water bodies & thousand rubles & 0 & 368,32 \\
\hline $\begin{array}{l}\text { Production and consumption waste } \\
\text { disposal }\end{array}$ & thousand rubles & 2332.35 & 2479.67 \\
\hline Pollution fee, including: & thousand rubles & 120.10 & 110.93 \\
\hline Air pollution & thousand rubles & 80.01 & 76.18 \\
\hline Contamination of water bodies & thousand rubles & 0 & 2.55 \\
\hline $\begin{array}{l}\text { Production and consumption waste } \\
\text { disposal }\end{array}$ & thousand rubles & 40.09 & 32.20 \\
\hline Excess pollution fee, including: & thousand rubles & 106.57 & 77.14 \\
\hline Air pollution & thousand rubles & 69.18 & 57.68 \\
\hline Contamination of water bodies & thousand rubles & 0 & 1.17 \\
\hline $\begin{array}{l}\text { Production and consumption waste } \\
\text { disposal }\end{array}$ & thousand rubles & 37.39 & 18.29 \\
\hline $\begin{array}{l}\text { Percentage of excess pollution fee, } \\
\text { including: }\end{array}$ & $\%$ & 88.73 & 69.54 \\
\hline Air pollution & $\%$ & 86.46 & 75.72 \\
\hline Contamination of water bodies & $\%$ & 0 & 45.88 \\
\hline $\begin{array}{l}\text { Production and consumption waste } \\
\text { disposal }\end{array}$ & $\%$ & 93.27 & 56.80 \\
\hline $\begin{array}{l}\text { Coefficient of economic damage } \\
\text { compensation, including: }\end{array}$ & $\%$ & 4.12 & 3.22 \\
\hline Air pollution & $\%$ & 13.76 & 12.71 \\
\hline Contamination of water bodies & $\%$ & 0 & 0.69 \\
\hline $\begin{array}{l}\text { Production and consumption waste } \\
\text { disposal }\end{array}$ & $\%$ & 1.72 & 1.30 \\
\hline
\end{tabular}

Table 1 shows the damage caused by production and consumption waste disposal (2332.35 thousand rubles in 2013 and 2479.67 thousand rubles in 2014) has the maximum value in the total economic damage amount. If we consider the dynamics of economic losses in 2014 compared with that of 2013, it was an increase in environmental pollution in all components (air pollution - by the 18 thousand rubles or by $3.1 \%$, water pollution - by 368.32 thousand rubles, industrial waste and consumption disposal - by 147.32 thousand rubles or $6.32 \%$ ). As a result of the overall increase in economic losses amounted to 533.64 thousand rubles or $18.32 \%$.

The pollution fee in 2014 compared with 2013 decreased by 9.17 thousand rubles or by $7.64 \%$; the water pollution fee appearing in 2014 (2.55 thousand rubles).

The hazardous eco-economic factor is that the company has a high proportion of excess pollution fee that adversely affects its financial results. In particular, in 2013 this figure was $88.73 \%$ and in $2014-69.54 \%$. Considering the individual environment elements, the maximum percentage is observed in air pollution and production and consumption waste disposal in 2013 (respectively $86.46 \%$ and 93.27\%). In addition, there is the pollution of water bodies with the high proportion of excessive pollution fee in $2014-45 \%$.

The important integrated environmental-economic indicator is the coefficient of economic damage compensation, which has a maximum value in air pollution $(13.76 \%$ in 2013 and $12.71 \%$ in 2014). The situation of pollution of water bodies and production and consumption waste is even less favorable, in particular, the indicator for contamination of water bodies in 2014 is $0.69 \%$ (in 2013 there was no water pollution), production and consumption waste $-1.72 \%$ in 2013 and $1.3 \%$ in 2014 . In general, taking into consideration all environment elements, this ratio amounted to $4.12 \%$ in 2013 and $3.22 \%$ in 2014. The economic damage compensation factor allows making a conclusion that the environmental management of the enterprise is not efficient enough.

To assess the environmental safety, the environmental and economic risk study methods $[11,12]$ can be used and the following differentiated range of values of the most reliable environmental and economic indicators is proposed (Table 2).

Table 2. Range of values of some environmental and economic indicators

\begin{tabular}{|c|c|c|}
\hline Range of values & $\begin{array}{c}\text { Percentage } \\
\text { of excess pollution fee, } \%\end{array}$ & $\begin{array}{c}\text { Coefficient of economic } \\
\text { damage compensation, } \%\end{array}$ \\
\hline Allowable & $0-25$ & More than 50 \\
\hline Limit & $25-50$ & $25-50$ \\
\hline Critical & $50-75$ & $5-25$ \\
\hline Unallowable & $75-100$ & Less than 5 \\
\hline
\end{tabular}

In accordance with the proposed system of environmental safety evaluation the proportion of excess pollution fees corresponds to the unallowable range of values in 2013 (88.73\%), the critical range of values in $2014(69.54 \%)$. If we consider the separate elements of the environment, in 2013 all figures correspond to unallowable range of values (there was no contamination of the water body). In 2014, air pollution comply with unallowable range of values $(75.72 \%)$, 
production and consumption waste disposal - the critical range of values $(56.80 \%)$, and water pollution - the limit range of values $(45.88 \%)$.

The economic damage compensation coefficient in general for all environment elements for the entire study period can be identified as corresponding to unallowable range of values. A similar situation exists for contamination of water bodies and production and consumption waste disposal, and air pollution indicator corresponds to the critical range of values.

In general, the analysis of environmental and economic indicators leads to the conclusion about the feasibility of the activities aimed at the improvement of the environmental safety management system of the enterprise, which is particularly important for such sectors of the environment as soil (production and consumption of waste disposal), in which the economic damage amounted to 2332.35 thousand rubles in 2013 and 2479.67 thousand rubles in 2014. This conclusion is further supported by the interpretation of the indicators "Percentage of excess pollution fee" and "Coefficient of economic damage compensation", which in most cases correspond to the unallowable range of values.

As it follows from Fig. 1, the final unit after the interpretation of the calculated environmental and economic indicators is the development of the proposals for improving the management decision-making support mechanism aimed at ensuring the environmental safety of the enterprise by reducing the anthropogenic impact on the environment and improving the technical and economic performance.

One of these management decisions derived from the analysis of economic damage structure, which showed that the maximum economic damage is caused by the waste of the 4th class of hazard (mainly ash and slag waste from the boiler plants) - 2324.19 thousand rubles in 2013 and 2424.32 thousand rubles in 2014. For this reason, the processing of slag waste to produce building materials is proposed. The problem of disposal of ash and slag waste (10-15\% of the processed coal input) produced by industrial solid-fuel boiler plants is quite relevant $[13,14]$.

Ash wastes are the source of increased environmental hazards, and have a negative impact on the population (health) and the environment, as well as the cause of the alienation of land, which is almost permanently withdrawn from the use.

Another solution is the use of the accelerated depreciation rate for fixed production assets in order to reduce pollution fees. This solution will permit:

- to accelerate the process of updating the active part of basic production assets of the company;

- to accumulate the sufficient funds (depreciation allowance) for the production modernization and reconstruction in order to reduce the anthropogenic impact on the environment;

- to avoid moral and physical deterioration of the active part of basic production assets in order to maintain them at a high technical level, creating good basis for the gain in production, the improvement of production quality and its cost reduction.
It's estimated that the increase in equipment depreciation by $0.1-1.0 \%$ leads to the reduction of negative impacts on the environment up to $10 \%$.

The significant source of air emissions at the plant is the outdoor coal storage with a capacity of 50 thousand tons of coal, which causes the significant economic damage, without taking into account the implicit losses associated with the deterioration of the stored coal consumption indicators, and more severe working conditions of workers.

In connection therewith it is proposed to convert the outdoor coal storage into the indoor structure, which has the following advantages:

- compactness;

- full mechanization of rehandling operations;

- the ability to use the storage as the metering compartment;

- coal protection from wind and precipitation;

- coal loss free rehandling conditions.

The conceptual proposals are the introduction of environmental management system - the part of the general management system that includes the organizational structure, activity planning, allocation of responsibilities, practical work, as well as the procedures, processes and resources for developing, implementing, assessing the progress of implementation and improvement of environmental policies, goals and objectives.

The environmental management system enables an organization to structure, to tie together the processes aimed at achieving the continuous improvement, the desired degree of which is defined by the organization itself, depending on the economic and other conditions $[15,16,17]$.

For the open-pit coal mining enterprises or the coal producers applying a complex scheme of coal mining, it is advisable to use the innovative technology, aimed not only at improving the blasting efficiency, but also at improving the environmental safety by reducing emissions containing nitrogen oxides [18].

The additional research attention should be paid to various technologies for waste treatment and use in economic turnover, proving their environmental and economic efficiency, such as the innovative method of mined-out working stowage, minimizing the negative impact on the environment [19, 20, 21].

\section{CONCLUSION}

The conducted study of the efficiency of the environmental safety management system of JSC "Open-pit Inskoy" with the aim to improve the management decision-making support mechanism, led to the following conclusions:

- the notion of environmental safety of the coal enterprises is refined;

- the algorithm for the assessment of the environmental safety management efficiency is developed;

- the scheme of evaluation of basic environmental and economic indicators of the coal enterprises characterizing the level of its environmental safety is proposed and implemented; 
- the range of environmental and economic performance values is proposed within the context of the methods for the study of environmental and economic risks of the coal mining enterprises;

- the proposals for the improvement of management decision-making support mechanism aimed at ensuring the ecological safety of the coal-mining enterprises by reducing the anthropogenic impact on the environment and improving the technical and economic indicators are developed.

\section{REFERENCES}

[1] Zhidko E.A. Problemy organizatsii upravleniya ekologicheskoy bezopasnostyu na promyshlennom predpriyatii [Problems Pertaining to Organization of Environmental Safety Control at an Industrial Enterprise]. Bezopasnost truda v promyshlennosti [Occupational safety in industry]. 2010. No. 8. P. 38-42.

[2] Schastlivcev E.L., Stepanov Yu.A., Korchagina T.V. Vliyanie ugledobychi na formirovanie tekhnogennykh landshaftov [The impact of coal mining on the formation of man-made landscapes]. Vestnik kuzbasskogo gosudarstvennogo tehnicheskogo univeristeta [Vestnik of Kuzbass State Technical University]. 2007. No. 1. P. 78-80.

[3] Kovalev V.A., Potapov V.P., Schastlivcev E.L. Monitoring sostoyaniya prirodnoy sredy ugledobyvayushhikh rajonov Kuzbassa [Monitoring of the natural environment state of Kuzbass coal-mining areas]. Novosibirsk, Publisher of Siberian Branch of the Russian Academy of Sciences. 2013. $312 \mathrm{P}$.

[4] Kachurin N.M., Efimov V.I., Vorobev S.A. Metodika prognozirovaniya ekologicheskikh posledstviy podzemnoy dobychi uglya $\mathrm{V}$ Rossii [Methods for the forecast of the environmental impacts of underground coal mining in Russia]. Gorny zhurnal [Mining Journal]. 2014. No. 9. P. 138-142.

[5] Petrov I.V., Sekistova N.A., Kharkov A.I. Voprosy ekologicheskoy bezopasnosti $\mathrm{v}$ novykh usloviyakh formirovaniya vzaimootnosheniy $\mathrm{v}$ ugolnoy promyshlennosti [The challenges of ecological safety in the conditions of forming the interrelations in coal mining industry]. Gorniy informatsionno-analiticheskiy byulleten [Mining informational and analytical bulletin]. 2009. No. 6. P. 261-263.

[6] Astakhov A.S., Dikolenko E.Ya., Kharchenko A.S. Ekologicheskaya bezopasnost i effektivnost prirodopolzovaniya [Environmental safety and nature management efficiency]. Moscow, Mining book, 2009. 323 P.

[7] Skryl O.K. Sistema podderzhki prinyatiya resheniy v upravlenii ekonomicheskoy ustoychivost'yu promyshlennogo predpriyatiya [Decision support system in management by economic stability of industrial enterprise]. Vestnik kuzbasskogo gosudarstvennogo tehnicheskogo univeristeta [Vestnik of Kuzbass State Technical University]. 2015. No. 5. P. 222-227.

[8] Mikhailov V.G., Bugrova S.M. Sovershenstvovanie sistemy upravleniya ekologo-ekonomicheskoy bezopasnostyu na ZAO "RAZREZ "INSKOY" [Improving the environmental and economic safety management system at JSC "Open-pit mine Inskoy"]. $V$ mire nauchnykh otkrytiy [In the World of Scientific Discoveries]. 2015. No. (66). P. 548-564.

[9] Galanina T.V. Ekologicheskie posledstviya pri razlichnykh klassakh tekhnogennykh vozdeystviy [Экологические последствия при различных классах техногенных воздействий]. Gorniy informatsionno-analiticheskiy byulleten [Mining informational and analytical bulletin]. 2009. Vol. 7. No. 12. P. 174-177.

[10] Stepanov Yu.A., Korchagina T.V. Ekspertnaya sistema dlya ekologicheskogo analiza i vyrabotki prirodookhrannykh meropriyatiy [Expert system for environmental analysis and the development of environmental actions]. Vestnik kuzbasskogo gosudarstvennogo tehnicheskogo univeristeta [Vestnik of Kuzbass State Technical University]. 2007. No. 3. P. 26-28.

[11] Busygin V.P., Puzanov Yu.V., Batyukhnova O.G., Zakharova P.V., Semenova I.V. Analiz ekologicheskogo riska [Environmental risk analysis]. Ekologicheskie sistemy $i$ pribory [Ecological Systems and Devices]. 2012. No. 4. P. 3-38.

[12] Mikhailov V.G., Koryakov A.G., Mikhailov G.S. Environmental risks management in the process of coal mining and processing. Journal of Mining Science. 2015. Volume 51, Issue 5.

[13] Dyakov S. N., Papin A. V., Nevedrov A. V. and Zhbyr E. V. Converting coal slurry to concentrate for coke production. Coke and Chemistry. 2012. Vol. 55. No. 10.

[14] Dyakov S. N., Nevedrov A. V. and Papin A. V. Fluorene production from coke-industry byproducts. Coke and Chemistry. 2012. Vol. 55. No. 9.

[15] Ubugunov L. L., Kulikov A. I. and Kulikov M. A. On the application of risk analysis technology for assessment of the ecological hazard of desertification (by the example of Republic of Buryatia). Contemporary problems of ecology. 2011. Vol. 4. No. 2.

[16] Mudretsov A. Ekologicheskaya bezopasnost: ekonomiko-pravovoe regulirovanie [Environmental security: economic and legal regulation]. Problemy teorii i praktiki upravleniya [Theoretical and Practical Aspects of Management]. - 2012. - No. 6. - C. 120-126.

[17] Ponomarenko D., Tanayants I., Grunicheva S. Upravlenie ekologicheskimi aspektami deyatelnosti [Environmental-related activity management]. TekhNadzor [TekhNadzor]. 2013. No. 2. P. 30-31.

[18] Kutuzov B.N. Povyshenie ekologicheskoy bezopasnosti pri massovykh vzryvakh na razreze OOO «Uchastok «Koksovyy» [Environmental Safety Increase During Mass Blasting at Open Pit LLC «Section «Koksovy»]. Bezopasnost truda v promyshlennosti [Occupational safety in industry]. 2010. No. 3. P. 30-33.

[19] Zaostrovtsev V. N., Minyaeva I. A., Sukhanevich M. M. and Gorev A. V. Technological complex of purification of return mining waters. Gornyi Zhurnal. 2014. No. 3.

[20] Perspektivy ekologicheski bezopasnogo ispolzovaniya otkhodov proizvodstva na territoriyakh gornodobyvayushchikh regionov [Prospects for the environmentally safe use of industrial wastes in mining regions] Kachurin N.M. [and others]. Bezopasnost truda v promyshlennosti [Occupational safety in industry]. 2014. No. 9. P. 81-84.

[21] Lyashenko V.I. Povyshenie ekologicheskoy bezopasnosti v gornodobyvayushchem regione [Increase of Ecological Safety in the Mining Region]. Bezopasnost truda v promyshlennosti [Occupational safety in industry]. 2014. No. 12. P. 54-59. 